\title{
Why Low Political Participation of Rural Women in China: An Interpretation from Neo-Institutionalism Perspective
}

\author{
Cui Huang \\ Department of Public Administration, Dalian University of Technology, Dalian, China \\ Email: huangcui42@dlut.edu.cn
}

How to cite this paper: Huang, C. (2018). Why Low Political Participation of Rural Women in China: An Interpretation from Neo-Institutionalism Perspective. Open Journal of Political Science, 8, 250-262. https://doi.org/10.4236/ojps.2018.83018

Received: May 25, 2018

Accepted: July 6, 2018

Published: July 9, 2018

Copyright $\odot 2018$ by author and Scientific Research Publishing Inc. This work is licensed under the Creative Commons Attribution International License (CC BY 4.0).

http://creativecommons.org/licenses/by/4.0/

\section{Open Access}

\begin{abstract}
Gender inequality still exists in China. One of its reasons and manifestations is the low political participation of rural women. The data analysis of 970 questionnaires reveals that current political participation of rural women is characterized by low number, lack of motivation and organization, and self-interest driven participation. This article seeks to interpret their low political participation from the perspective of neo-institutionalism. It argues that this low participation has been caused by informal institutions, such as the restraints of traditional gender concepts, women's lack of desire for personal rights and weak sense of organization, as well as by formal institutions, including imperfect policy system and women organizations in the rural areas. Consequently, improving rural women's political participation should start with reforming these institutions.
\end{abstract}

\section{Keywords}

Rural Women, Political Participation, Informal and Formal Institutions

\section{Introduction}

Gender inequality still exists in China. According to the Global Gender Gap Report (2016), China ranked $99^{\text {th }}$ in gender equality around the world. Since one key criteria of gender equality used in that Report was women's political participation, it is urgent for China to address this issue. In particular, rural women's political participation should be improved, which is the most fundamental political act and determines the number and level of overall women's political participation in China (World Economic Forum, 2016). With the development of the urban-and-rural dual economic system, many rural men have migrated to 
cities in search for better-paying jobs, leaving their wives behind in the rural areas. Thus rural women become an importance force in rural constructions or village policy making. In this respect, to encourage the political participation of rural women will not only contribute to gender equality in China, but also to the modernization of rural villages.

Now scholars differ as to the precise definition of political participation. One theory that has been widely accepted in the academia is proposed by the American political scientist, Samuel Huntington. Political participation, according to Huntington, is "the activities attempted by civilians to influence government decision-making" (Huntington, 1987). That is to say, the political participation is usually limited to the political action such as political election, political supervision, etc. But other scholars believe the arena of political participation should be expanded: "Meaningful political participation requires a broader definition of politics, which extends beyond the institution boundaries of the party-state to other domains of social and economic life" (Howell, 2006). Considering the subject of this research and their inequality in China, this paper defines "rural women's political participation" as their participation in village government and their influence on village decision-making through their roles in such general activities as village elections, meetings, and administrations as well as gender specific organizations such as Women's Federations.

\section{Literature Review}

Studies of women political participation by foreign scholars are closely connected with the raging feminist movement. They have explored the reasons of women's low political participation from multiple angles. Many agree that women's participation in political life is complex and always changing (Spirou, 2017). One important cause for their low status is the patriarchal system. As Altindal observed, under the control of patriarchy, women problems will never go away (Altındal, 2009). On a global scale, the level and competence of women's political participation has not been transformed in a fundamental way (Nor \& Gapur, 2011). Some scholars attribute it to tradition, psychology, lack of encouragement and preoccupation with democratic affairs (Kalita, 2016). Others owe it to ideology, women's education level, economic status, social culture and others (El-Ghannam, 2011). Rigid gender quotas from nation also affect women's enthusiasm for political participation (Paxton, 2010). That is to say, the social context of women's lives may limit their opportunities to participate, with family and work responsibilities restricting the time available for political activities (Conway, 2018). Even the acceptableness of women as political leaders has been much crippled by some gendered media representation of "the Fourth Power" (Mavin \& Patricia, 2010). Still, politically active women have reported high on positive affect and low on negative affect as compared to women who are politically-non-active (Vats, 2017). As a whole, foreign scholars have studied this 
problem in detail and concretely, and regarded political participation as a relation variable such as disability, scientific authority (Pitts, 2012), religious beliefs, gender consciousness and women's political participation (Cassese \& Holman, 2016).

Therefore, women's perceptions of political participation and political efficacy are needed to improve their participation (Feldman, Darmstadt, Kumar, \& Ruger, 2015). Gender quotas enhance not only women's political participation but also political competition (Huang, 2016). It can also be improved by deepening women's awareness of political and legal rights to create conditions for them to participate in decision-making on the local and national levels (Dalton, 2008). The "two-pronged" approach proposed by Jude Howell is representative. One is to promote equal right of speech for men and women in the ideological sense; the other is to improve women's technical skills in the material sense (Howell, 2006). At the same time, foreign scholars often emphasize the role of social organizations. They believe that a government should fund women organizations well and help develop them as to play their important role in advocating women political participation (Thun, 2014).

Chinese scholars have also explored rural women's political participation from many angles. They have reached the consensus that at present rural women have many difficulties in political participation, such as the marginalization of their rights to participate (Liu, 2009), the low percentage of their actual participation, lack of practices in effective participation, large regional differences, and the lack of systematic support ( $\mathrm{Li}, 2015)$. Political participation originates from complicated social background for rural women and is influenced by their social conditions, living environment and personal qualities. Among these, economic level is so critical that rural women's political participation is directly hindered by their low incomes (Zhang, Wang, \& Liu, 2009). Besides, their political participation is affected by their educational levels and the traditional culture surrounding them. Scholars generally believe that one of the barriers to rural women's higher voting rates is their lack of knowledge about their rights to vote and the actual process of voting (Pang \& Zeng, 2013). Because of the Confucian values they have been taught by their families, traditional gender concepts and labor divisions still exert a subtle influence upon rural women's orientations of values (Zhou \& Gong, 2014). Moreover, their political participation is affected by their ages, health conditions and the time they have for leisure (Lv, 2013). Thus, to increase rural women participation in political activities requires profound reform of the very foundation of political system, material incentives for women and strong advocacy for their participation (Guo, Wang, Zhang, \& Wu, 2016).

Thus, what scholars have studied concerning the realities of women political participation, the factors that affect it, and the strategic advice they propose all provide useful contexts for the present research. Still, rural women's political participation in China has not been sufficiently examined. Most studies are con- 
fined to a limited area of women political participation and do not focus on rural women as an independent group, who are distinct from urban women in multiple ways. This research seeks to make up for the deficiency. Based upon 970 questionnaires mainly covering 6 provinces, it presents the current situation of rural women's political participation, examines the institutional factors that restrict it from the perspective of neo-institutionalism and proposes corresponding strategies to promote their participation.

\section{Current Rural Women's Political Participation}

\subsection{Data Sources and Methodology}

The data of this research are collected from questionnaires about rural women's political participation in six provinces including Liaoning, Shandong, Henan, Hunan, Guizhou, and Ningxia. Every two provinces were selected from east, middle and west of China to make the questionnaire sample more representative. Altogether, 970 questionnaires were handed out by investigators in person and 920 were completed. A small proportion of rural women with very low level of education cannot understand the content of the questionnaires and the explanation of our investigators, so their questionnaires were not collected successfully. Among these, 913 can be used, which made the questionnaire efficacy of this study $94.2 \%$. Because rural women, especially those whose husbands have migrated to cities, are under enormous living pressure, we have included "difficulties" as part of the basic information and the statistics we received was as in Table 1.

Table 1. Statistics of samples' basic information.

\begin{tabular}{|c|c|c|c|}
\hline \multicolumn{2}{|c|}{ Sample distribution } & \multirow{2}{*}{$\begin{array}{c}\text { Number of samples } \\
167\end{array}$} & \multirow{2}{*}{$\begin{array}{c}\text { Percentage }(\%) \\
18\end{array}$} \\
\hline \multirow{6}{*}{ Age } & Under 30 & & \\
\hline & 31 to 40 years old & 358 & 40 \\
\hline & 41 to 50 years old & 367 & 40 \\
\hline & 50 and above & 21 & 2 \\
\hline & Illiterate & 110 & 12 \\
\hline & Elementary school & 250 & 27 \\
\hline \multirow[t]{6}{*}{ Education level } & Junior high school & 373 & 41 \\
\hline & High school & 94 & 10 \\
\hline & High school and above & 86 & 10 \\
\hline & Agricultural labor & 236 & 26 \\
\hline & Family income & 369 & 40 \\
\hline & House chores & 127 & 14 \\
\hline \multirow[t]{2}{*}{ Difficulties } & Children rearing & 148 & 16 \\
\hline & Health condition & 33 & 4 \\
\hline
\end{tabular}




\subsection{Present Situation of Women's Political Participation in Rural Areas}

\subsubsection{Overall Inadequate Political Participation}

The political participation of rural women refers primarily to their participation in village meetings, village administration and committee election. According to our research, the percentage of rural women political participation is low, which reveals its overall inadequacy. The numbers of women who responded "never" to participation in village meetings, administrations and election are much higher than those who responded "often" (see Figure 1).

Take village meeting as an example: $52 \%$ of rural women never participate, $35 \%$ of them occasionally participate, and only $13 \%$ often participate. This is not in line with the main data of The Third Survey of Chinese Women's Social Status, which claims that " $83.6 \%$ of rural women have participated in village committee elections in the past five years and $70.4 \%$ of them have made their efforts to know the candidates and to use their rights of vote in a deliberate way" (National Women Federation \& National Bureau of Statistics, 2011). As the present research shows, current rural women's political participation in China is not promising. The total amount of political participation needs to be increased.

\subsubsection{Lack of Enthusiasm for Political Participation}

With advancement in the grass-roots democratic reform of the political system in China, rural people who have high comprehensive quality, strong administration skills and passion to serve have increasingly become representatives of their village and have more opportunities to participate in village administration and decision-making, which pave the way for their participation in village political activities. But our survey shows that most representatives are men, not rural women. The latter are still not fully aware of their political rights and lack knowledge of the policies and regulations of villager administration. Besides, they are not motivated or interested to participate. If they have domestic difficulties, they will mostly resort to their neighbors for help. When it comes to village matters, they often display passivity in language and action. When asked

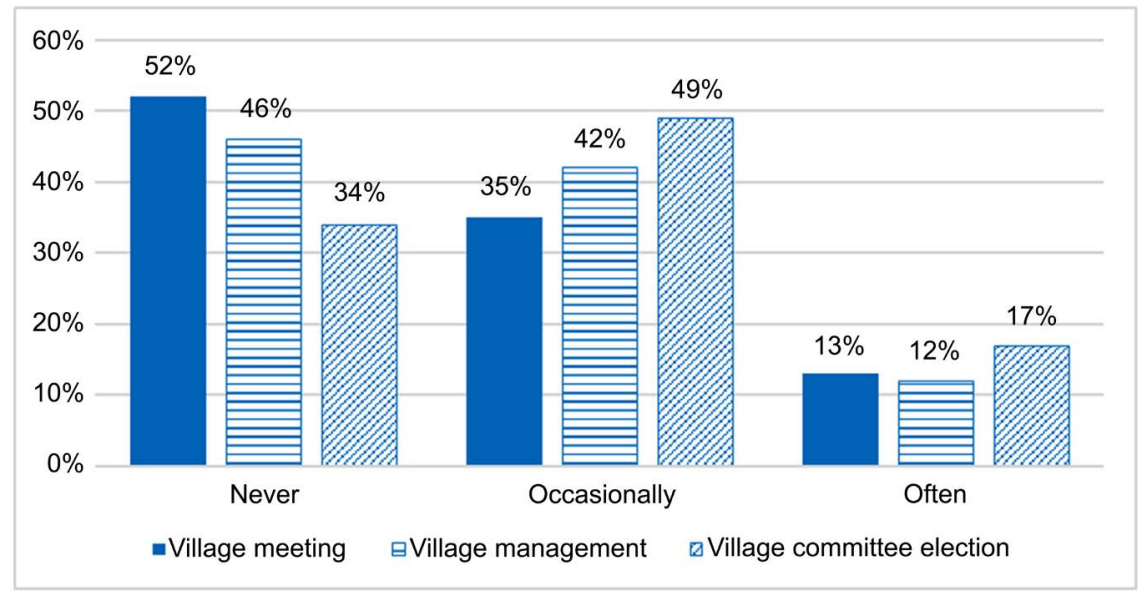

Figure 1. Rural women's political participation in villages' affairs. 
whether they would actively take part in politics, most of them answered equivocally that it all depends. Only few people gave some certain answers. As for the reasons of their non-participation in village affairs (see Figure 2), 41\% women have "no time and energy," $40 \%$ of them believe it is none of their business, and $19 \%$ of them simply do not care. These numbers unmistakably point to the lack of intrinsic motivation for rural women to participate in political activities.

\subsubsection{Private Interest in Political Participation}

Related to rural women's lack of intrinsic motivation is their self-interest when they do participate in public activities. In other words, current rural women's political participation is predominantly driven by self-interest. As shown in Figure $3,44 \%$ of rural women attend village affairs only when these are relevant to their lives, $35 \%$ of them simply follow others or accompany their neighbors, while only $6 \%$ of the women attend to express their views. This reveals that current village decision-making does not depend entirely on the male elite. Rural women contribute to it as well, even though out of their self-interest.

\subsubsection{Low Degree of Organization}

In this paper, women organizations such as Women's Federation is taken as an indicator of their political participation because how close women relate to these organizations reflect their relationship with public agencies in general. Women's Federation in rural areas is formed to protect the rights and benefits of local women and should fulfill its roles in women life by awakening them to their rights, enlarging their public roles, and promoting their participation in political activities. But our research shows rural women are not closely connected with Women's Federation because of its weak political functions and their emotional detachment from it. Figure 4 shows that $52 \%$ of the women have never contacted Women's Federation, 31\% have occasionally contacted them and only $17 \%$ have been in frequent contact with the Federation. When asked whether their local Women's Federation was helpful in any way to their life, nearly 50\% of the women replied "just a little" while $28 \%$ replied "none."

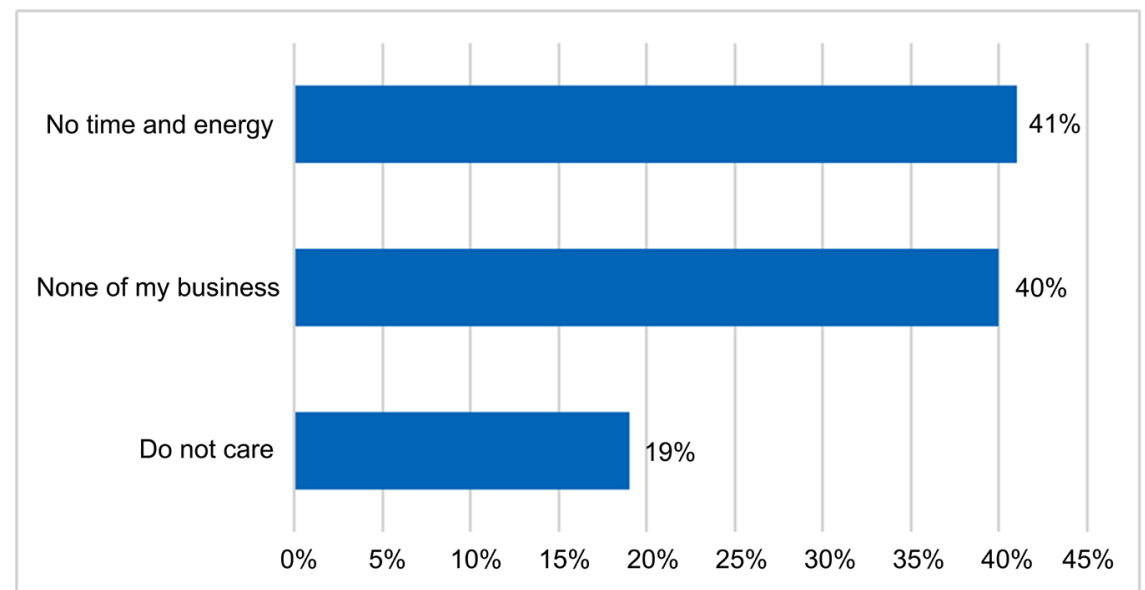

Figure 2. Intrinsic motivation of rural women in village affairs. 


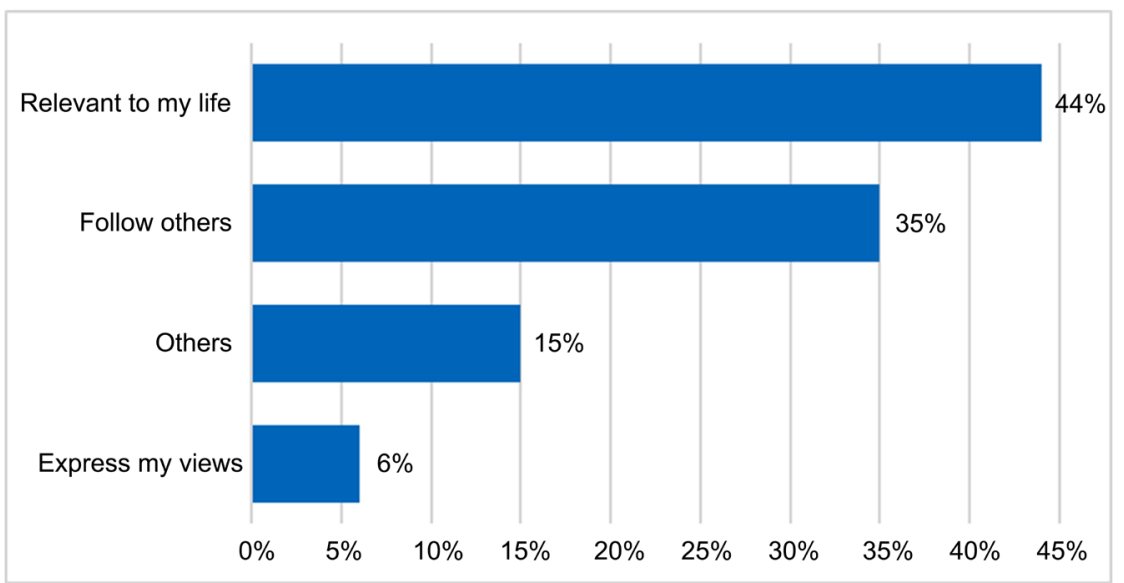

Figure 3. Private interests of rural women's political participation.

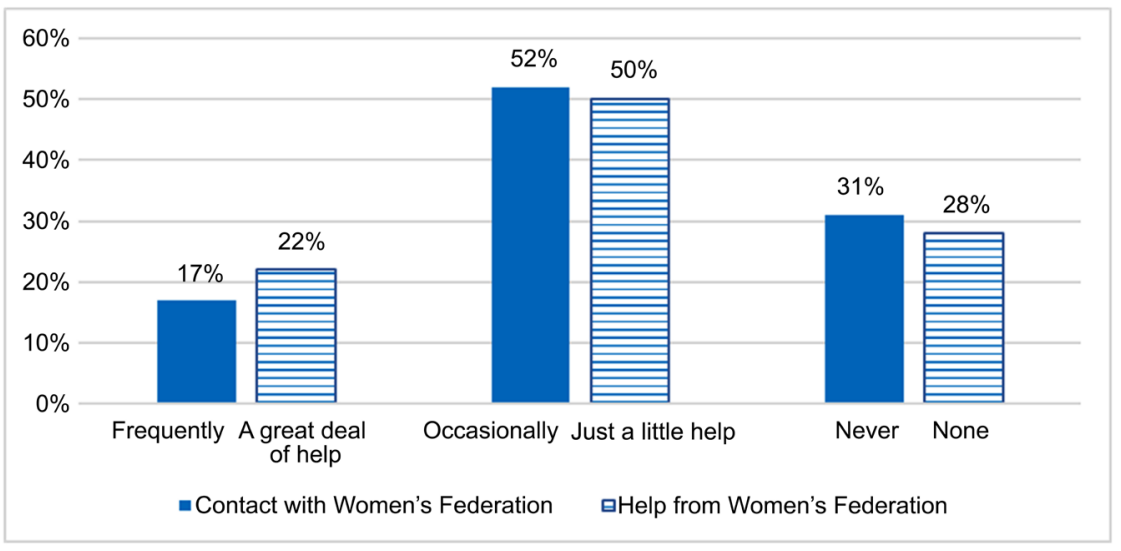

Figure 4. Rural women's contact with women's federation and the help from women's federation.

\section{The Institutional Factors That Constrain Rural Women's Political Participation}

Neo-institutionalism has emerged in recent years as a mainstream paradigm in social sciences. Although as a theory it has been criticized, it has provided a new perspective to academic research with its unique definitions of institution. "Neo-institutionalism is concerned with both the informal conventions in political life and the formal institutional charters and organizational structures" (Marsh, 2002). Institution has two levels of meaning in neo-institutionalism: informal institutions such as ethical standards, traditional customs, religious beliefs, and formal institutions such as policies, regulations, and rules of procedure. At present, the political participation of rural women in China is constrained by these two levels of informal and formal institutions.

\subsection{Informal Institutions That Constrain Rural Women's Political Participation}

\subsubsection{Traditional Gender Concepts}

Some old gender concepts in traditional Chinese culture still impact the though- 
ts and acts of people today, such as "preference for boys over girls" and "women inferiority to men." Women have been assigned to the private area of home in the process of socialization. The education they have received since childhood aims at cultivating in them those qualities pertaining to the wife and mother. As a result, they have not developed those qualities necessary for political leadership and participation when they grow up and have little desire for leadership or rights, hence their little participation in actual public activities (Li, 2002: P. 236). The statistics of gender concepts and attitudes in The Third Survey of Women Status in China show that while a vast majority of respondents believe women are not less capable than men, 55\% of them agree that "men should be socially-orientated and women should be domestically-orientated" (National Women Federation \& National Bureau of Statistics, 2011). Rural women are under many constraints, which directly inhibit their sense of political efficacy. Our research reveals that some women have only received primary education because their parents do not believe in the value of educating girls and prefer to send them to work at an earlier age. The result the low level of education among many rural women, which in turn affect their capability of political participation and political efficacy. Political efficacy is an individual's cognition and subjectivity concerning his/her capability to impact decision-making and actions. As American political scientist Dahl said, "If you think what you do does not matter since you can't effectively change the result in any way, then you are unlikely to intervene in politics." The degree of people's political participation is positively related with their political efficacy. This has been confirmed by our survey. When asked the reasons why they did not participate in the election of village committee, $40 \%$ of the women attributed it to lack of time and energy, $23 \%$ of them to the uselessness of participation, and $25 \%$ of them to their ignorance of the content and procedure of election. As for the reasons of their participating in community activities, only $7.7 \%$ of them believe their participation will have an impact upon the community. The majority of rural women have low political efficacy, which results in their little participation.

\subsubsection{Rural Women's Limited Desire for Power}

Rural women are often motivated by their own material interests to participate in political activities. In the rural society, people usually act from their desires. Compared with the people in modern urban society, rural women's needs are mostly of the basic types, such as their physiological needs and those needs for security and mere subsistence. As Mr. Xiaotong Fei pointed out, "those who hold power with consent were not meant to protect their own special interests" (Fei, 2011). "The power of consent" is based upon the social contract, which is authorized by the people and exercised on behalf of the public. It is different from the oppressive "violent power" imposed by the ruling class. Only when people are freed from economic worries will they have higher demands, stronger desire for power, and greater motivation for action. It costs rural women more than men to gain "the power of consent." At the same time, they are under great 
life pressures to raise their children, care for the elderly in their families and fulfill their duties as wives. Consequently, they tend to pay more attention to the economic benefits that are directly related to their lives and have very limited desire for political power.

\subsubsection{Concept of Family Culture}

Together with the lack of social organizations and low functioning of Women's Federation, the profound influences of "family culture" in rural areas result in rural women's lack of trust in public organizations. Rural China is a society where people were brought up and buried in the same place they were born. Usually those with the same last name in the village belong to the same clan. In everyday life, rural people tend to seek help from their family clans or interest groups rather than forming an organization upon common goals and drawing help from it. As our survey shows, $13 \%$ of women have totally rejected setting up any special mutual-aid organizations to improve their conditions. When asked whether they would seek help from Women's Federation in time of trouble, more than half of the women would only if they were unclear about certain policies involved. When they have domestic difficulties, they usually ask their neighbors or family clans to help resolve them. In addition, under the influence of the traditional wisdom not to publicize domestic trouble, they rarely seek help from any "outsiders," but rather turn to their families and close friends for help. At the same time, the undeveloped nature of civil organizations in rural areas have weakened people's trust and dependence on them. Most of these civil organizations are not functioning well, so the help they offer is limited. This results in women's lack of trust in public organizations and in turn thwarts their active participation in political matters.

\subsection{Formal Institutions That Constrain}

\subsubsection{Imperfect Policy System}

There are many systems and regulations about women's political participation in China, but they need to be improved. Take Article 9 of The Laws of Organizing Village Committee of the People's Republic of China (1998) for an example. It stipulates: "There should be an appropriate quota of women among the members of the village committee." Accordingly, local governments have various policies to ensure the proportional presence of women on village committees. But these policies and regulations do not set up any clear and definite measures to carry them out. In practice, such expressions as "appropriate quota" and "a certain proportion" are ambivalent and can be understood in different ways. It can be satisfied even when a village committee has only a woman member. In a Women's Federation, usually the only woman is the director while other positions are taken up by males. This varied and flawed understanding of regulations has seriously affected rural women's political participation. Moreover, it is hindered by the village autonomy system. Take the election of a village committee as an example. To make sure that those elected will be advantageous to their in- 
terests, some local governments interfere in the election itself and damage its democratic character. Besides, bribery is rampant during the election. Some candidates try to ensure their election by buying votes, bribing superiors, and promising financial returns to their constituents. In reality, many village leaders have been in position for many years. The prevalence of corruption in village administration has wrought such a deep and negative impression upon rural women that it has severely affected their motivations and zeal for political participation.

\subsubsection{Weak Women's Grassroots Organizations}

At present, Women's Federations and Women's Congress are the two main women organizations in rural areas. They play an important role in supporting rural women's political participation. As the only national women's social organization, the Women's Federation connects people to the Party and government and should promote rural women's participation in politics. But in reality, Women's Federation in rural areas has greatly failed in this respect. Because it is attached to its superiors and has no authority or power within itself, it serves as their propaganda tool to repeat their directions. Its actual work is mainly to accomplish the tasks set by the government or its superior Women's Federation. Thus, its effect on rural women's political participation is rather limited. Likewise, grassroots Women's Congress is no better than the Women's Federation. Its work at all levels depends on the "double committee" (Party branch committee and villagers' autonomy committee). Even its director is appointed directly by "the double committee," which makes her election a mere formality (Liu, 2005). This lack of autonomy for the Women's Federation and the Women's Congress makes it difficult for them to develop political rights awareness in women. Consequently, women do not have the resources of organization or the power they need for effective political participation.

\section{Conclusion}

The political participation of rural women is related to the democratic political construction in China. Promoting their political participation is an important task in this epoch of enhancing national administration competence and modernizing administration system. Based upon sufficient statistics, this paper has examined the current situation of rural women's political participation in China and found that it is insufficient in terms of the number of women participating, their lack of motivations, their motives of self-interest, and low degree of organizations. This is the result of both informal and formal institutional defects and constraints. The informal institutions include the constraints from traditional gender concepts, limited political desires of women and their weak sense of organization. Among the formal institutions, relevant policies such as the women's proportion in a village committee need to be perfected and current women organizations in rural rears are rather weak. 
Consequently, the expansion of rural women's political participation can be attempted from the perspectives of these two institutions. With respect to the informal institutions, women's political participation awareness can be cultivated through education and their political efficacy be enhanced through the role models of women leaders in rural areas. On the part of formal institutions, systems relevant to women political participation should be clarified and improved. Mechanism of rewards and punishments should be set up to encourage them to participate actively in political life. At the same time, the unique functions of such grassroots social organizations as rural Women Federation should be brought into play.

\section{Funding}

This paper is supported by General Project of the National Social Science Fund in China Research on the Organizational Development of Rural Women in Rural Governance (17BZZ065) and the Liaoning Province Academy of Social Sciences Planning Fund Project (key project) Research on the Promotion Paths of Liaoning Rural Left-Behind Women's Organizing (L15ASH002).

\section{References}

Altındal, Y. (2009). Powerless Doublures of Masculin Politics. Balkesir Üniversitesi Sosyal Bilimler Dergisi, 21, 351-367.

Cassese, E. C., \& Holman, M. R. (2016). Religious Beliefs, Gender Consciousness, and Women's Political Participation. Sex Roles, 75, 514-527. https://doi.org/10.1007/s11199-016-0635-9

Conway, M. M. (2018). Women's Political Participation at the State and Local Level in the United States. PS Online. https://www.apsanet.org/

Dalton, R. J. (2008). Citizenship Norms and the Expansion of Political Participation. Political Studies, 56, 76-98. https://doi.org/10.1111/j.1467-9248.2007.00718.x

El-Ghannam, A. R. (2011). Analytical Study of Women's Participation in Political Life in Arab Societies. Equal Opportunities International, 22, 38-53. https://doi.org/10.1108/02610150310787522

Fei, X. (2011). Native China. Beijing: Commercial Press.

Feldman, C. H., Darmstadt, G. L., Kumar, V., \& Ruger, J. P. (2015). Women's Political Participation and Health: A Health Capability Study in Rural India. Journal of Health Politics, Policy and Law, 40, 101-164. https://doi.org/10.1215/03616878-2854621

Guo, J., Wang, C., Zhang, B., \& Wu, G. (2016). An Analysis of the Attitude and Behavior Logic of Rural Women's Political Participation in the Transition Period: Exemplified by the Five Provinces (Regions) of Su, Liao, Gan, Ning and Guizhou. Chinese Rural Observation, 3, 27-40.

Howell, J. (2006). Women's Political Participation in China: In Whose Interests Elections? Journal of Contemporary China, 49, 603-619. https://doi.org/10.1080/10670560600836614

Huang, C. L. (2016). Reserved for Whom? The Electoral Impact of Gender Quotas in Taiwan. Pacific Affairs, 89, 325-343. https://doi.org/10.5509/2016892325

Huntington, N. (1987). Difficult Choice: Political Participation of Developing Countries. 
Xiaoshou Wang Translation. Beijing: Huaxia Press.

Jude, H. (2002). Women's Political Participation in China: Struggling to Hold up Half the Sky. Parliamentary Affairs, 55, 43-56. https://doi.org/10.1093/parlij/55.1.43

Kalita, J. (2016). Representation of Women in Politics: A Need for National Development. International Multidisciplinary Journal, 5, 54-58. https://doi.org/10.5958/2277-937X.2016.00031.9

Li, H. (2002). Gender and Public Policy. Beijing: Contemporary China Press.

Li, Y. (2015). Reflections on the Predicament of Women's Political Participation in Grassroots Ethnic Groups in Chinese Countryside. Journal of Yunnan University for Nationalities, 2, 116-121.

Liu, X. (2005). Tanggu Model: Taking Gender Awareness into Mainstreaming of Villager Autonomy. Collection of Women's Studies, 5, 18-25.

Liu, X. (2009). Analysis on the Policy Factors of Rural Women's Political Participation's Difficulties. Hubei Social Science, 1, 51-53.

Lv, F. (2013). Village Political Participation and Its Influencing Factors of Rural Left-Behind Women: A Case Study of 660 Village Left-Behind Women in 16 Provinces. Journal of Beijing Institute of Administration, 6, 13-18.

Marsh, D. (2002). Theories and Methods of Political Science (2nd ed., Jing Y. et al. Translation). Beijing: Renmin University of China Press. https://doi.org/10.1007/978-0-230-62889-2

Mavin, S., \& Bryans, P. (2010). Fed-Up with Blair’s Babes, Gordon's Gals, Cameron's Cuties, Nick's Nymphets: Challenging Gendered Media Representations of Women Political Leaders. Gender in Management, 25, 550-569. https://doi.org/10.1108/17542411011081365

National Women Federation, National Bureau of Statistics (2011). Third Major Data Report on Chinese Women's Social Status Survey.

Nor, W. A. W. M., \& Gapur, S. A. (2011). Sustainable Democratic Governance: Some Issues in Women's Political Participation. Journal of US-China Public Administration, 4, 438-443.

Pang, X., \& Zeng, J. (2013). Does Women's Knowledge of Voting Rights Affect Their Voting Behaviour in Village Elections? Evidence from a Randomized Controlled Trial in China. The China Quarterly, 213, 39-59. https://doi.org/10.1017/S0305741012001531

Paxton, P. (2010). Growth in Women's Political Representation: A Longitudinal Exploration of Democracy, Electoral System and Gender Quotas. European Journal of Political Research, 49, 25-52. https://doi.org/10.1111/j.1475-6765.2009.01886.x

Pitts, Y. (2012). Disability, Scientific Authority, and Women's Political Participation at the Turn of the Twentieth-Century United States. Journal of Women's History, 24, 37-61. https://doi.org/10.1353/jowh.2012.0012

Spirou, M. E. (2017). The Challenges of Political Representation: Gender in a US State Legislature. International Journal of Public Leadership, 13, 13-25. https://doi.org/10.1108/IJPL-10-2016-0037

Thun, C. (2014). Women-Friendly Funding? Conditions for Women's Organizations to Engage in Critical Advocacy in Norway. NORA Nordic Journal of Feminist and Gender Research, 22, 100-115. https://doi.org/10.1080/08038740.2013.866158

Vats, P. (2017). Political Participation Leading to Life Satisfaction among Rural Women. Indian Journal of Health and Well-Being, 12, 1533-1534. 
World Economic Forum (2016). Global Gender Gap Report.

http://reports.weforum.org/global-gender-gap-report-2016/

Zhang, C., Wang, Y., \& Liu, F. (2009). Analysis on the Status Quo and Influencing Factors of Rural Women's participation in Villager Autonomy: A Case Study of Hebei Province. Guangdong Agricultural Science, 11, 274-277.

Zhou, Q., \& Gong, Z. (2014). A Study on the Political Participation of Minority Rural Women in Tacheng Area: A Case Study of the Daur Nationality in Asier Township of Tacheng City. Journal of Jiangxi Radio and Television University, 1, 44-49. 